\title{
Research Paper Breakeven analysis of custom hiring service centres operating in agriculture - An economic study in Karnataka
}

\section{P. S. Ranjith Kumar and G. S. Mahadevaiah}

Correspondence to :

P.S. Ranjith Kumar Department of Agricultural Economics, University of Agricultural Sciences, G.K.V.K., Bengaluru (Karnataka) India

Paper History :

Received : 21.08.2017;

Revised : 25.01 .2018

Accepted : 09.02.2018
ABSTRACT : The present study has been carried out in Eastern dry of Karnataka with objective of analyzing the feasibility of CHSCs and to document the farm machinery generating higher incomes to CHSC in the study region. The primary data for the study has been collected from the 30 custom hire service (CHS) providers comprise of government sponsored CHSCs operated by NGOs and private firms and farmers owning farm machinery for CHS in the study region by following purpose multistage random sampling procedure. The study highlighted that the farmer CHS providers own farm machinery which are having greater demand from the users and able to generate higher profits in shorter period of time. The break point analysis showed all the machinery owned by farmers is capable of generating higher incomes. While in case of government sponsored CHSCs, the breakeven point analysis showed that some of the implement such as brush cutter, ground nut pod stripper, power tiller, ragi reapear and rotary tiller were unable to cover even the fixed and variable costs occurred an account use of these machinery. It indicates owning these machineries/implements are unworthy and can think of replacing theses with the machineries which are in great demand from the farmers.

Key Words : Custom hire services, CHSCs, Farm machinery, Farm mechanization, BEP

How To Cite This PAPer : Kumar, P.S. Ranjith and Mahadevaiah, G.S. (2018). Breakeven analysis of custom hiring service centres operating in agriculture - An economic study in Karnataka. Internat. Res. J. Agric. Eco. \& Stat., 9 (1) : 141-148, DOI : 10.15740/HAS/IRJAES/9.1/141-148. 